\title{
Electric and gas-generating tractors in the agricultural sector of the South of Russia in the 1930s: mass-staffs and application features
}

\author{
Vitalij Bondarev ${ }^{1}$, Ruslan Tikidzhyan ${ }^{1, *}$, and Olga Baryshnikova $^{1}$ \\ ${ }^{1}$ Don State Technical University, 1, Gagarin sq., 344003, Rostov-on-Don, Russia
}

\begin{abstract}
The article is based on the materials of the Don, Kuban and Stavropol regions as the most important agricultural regions of Russia, highlights the process of development and introduction of gas-generating tractors in Soviet agriculture during the 1930s, which represented a special direction of mechanization of agricultural production in the period under review. The author's statement that in the 1930s the author's work was carried out is convincingly justified. Representatives of the Party-Soviet leadership paid close attention to the development of gas-generating equipment as consuming cheaper fuel in comparison with petroleum products and it led to the rapid development of these technical devices and their quantitative growth, including in Soviet and collective farms. It was proved that, despite the efforts of the designers, gas-generating tractors had a number of significant drawbacks, which made their operation difficult and became one of the most important reasons for their usage stopping in agriculture.
\end{abstract}

\section{Introduction}

In the 1930s, the Soviet Union developed a rapid mechanization of agriculture, the leading device of which in agriculture was a tractor, capable of processing huge land areas, transporting trailed agricultural equipment, and transporting a variety of goods. In addition to the quantitative saturation of agriculture with tractors in the 1930s, work was carried out on their improvement, increasing their efficiency. One of the areas of tractor fleet optimization was the development of innovative models of tractors, in which the internal combustion engine was replaced by an electric motor or a gas generator set.

The history of agricultural machinery and tractor development is devoted to a huge layer of published scientific and theoretical relevance scientific literature among other things over the past few years [1-12]. Close attention is also paid to the history of technology with electric and gas-generating engines, including due to the practical significance of these issues: for example, gas-generating installations are still widely used in the economy and everyday life. It is possible to indicate a number of relatively recent works on gas-generating tractors in the Soviet Union $[13,14]$. However, the analysis of scientific literature in the regional context indicates the extreme heterogeneity of its

*Corresponding author: ruslan.kazak61@gmail.com 
coverage. If the problems of the development of electric and gas-generating equipment are studied in sufficient detail in the all-Russian mass headquarters, then this topic needs further study within the borders of individual regions. In particular, the topic of the use of electric and gas-generating tractors in agriculture in the Don, Kuban and Stavropol regions in the 1930s was studied only in fragments. All this gives this topic an undoubted, and therefore we have dedicated this publication to it.

\section{Materials and Methods}

The basic sourcesof our research were archival materials and periodicals of the 1930s. Among the archival documents, we should note the materials stored in the Russian State Archive of Socio-Political History (RSASPH) on the mechanization and, in particular, the tractorization of agricultural production in the North Caucasus Region in the 19290s 1930s (the North Caucasus Region existed in 1924-1933, combining the territories of the modern Rostov Region, Krasnodar and Stavropol territories). These documents provide an opportunity to trace the dynamics of the tractor fleet in the South of Russia in the specified period of time.

From the point of view of the interest topic to us, the most informative periodicals are the magazines "Automotive and tractor business", "Mechanization and Electrification of socialist agriculture", "Socialist Agriculture". It contains very detailed articles, the authors of which, either test engineers or the journalists, directly observingthe tests, narrated progress and results of experiments with electric and gas-generating tractors.

The leading research methods were historical-genetic and content analysis. The first of them allows you to follow developmenttrends and features of the electrical and gas generators in the 1930s, the second one is essential when certain semantic units are calculated in the study of literature and periodicals, whereby it is possible to form an opinion about the interest dynamics of contemporaries to electrical and gas generators, but also to identify the most significant advantages and disadvantages of this technique.

\section{Results}

Being important producers of agricultural products, the southern Russian regions since the 1920 s were among the primary recipients of equipment fromstate and cooperative trade organizations. And they were the leaders in the number of tractors among other regions of the Russian Soviet Federative Socialist Republic. There were 17,222 tractors in 1927 in the Russian Soviet Federative Socialist Republic, 4,963 of which were located in the North Caucasus Region - where the Don, Kuban, and Stavropol regions were united at that time. The share of the Southern Russian regions ' truck fleet in comparison with the total number of trucks in Soviet Russia was over $28.8 \%$. In second place was the Central Agricultural Region (about $17 \%$ of the tractor fleet of the RSFSR), the Lower Volga Region (10.7\%), etc. (RSASPH, f. 17, r. 85, d. 134, p. 233). In a number of districts of the North Caucasus Region tractors played an important role in agricultural work in 1927, as shown in Table 1 (RSASPH, f. 17, r. 85, d. 267p. 88).

As the industrialization of collectivization unfolded, the number of agricultural machinery in the south of Russia steadily increased. First of all, this applied to tractors as the most important mechanisms which were capable to perform a variety of tasks and participate in a variety of agricultural operations-from plowing and sowing (where tractors transported plows, seeders and harrows across the field) to harvesting (during which tractors were again used as a draft force, moving combines that were not yet self propelled in the time period under review). Sometimes tractors were used when threshing 
mown crops: in this case, the engine was used to drive the thresher. Of course, tractors were also used to transport a wide variety of goods. Therefore, it is not surprising that the number of tractors and their capacity determined the degree of agricultural production mechanization in the 1920 s -1930 s.

Already in the early 1930s, the scale of tractor deliveries hadincreased to the North Caucasus Region. From 1933 to 1937, the number of tractors wereincreasing from 20 thousand to 27 thousand to the Don and Kuban. The number of agricultural machinery working in the fields of collective farms and state farms in the South of Russia increased even more in the second half of the 1930s (despite the fact that in the third five-year plan, due to the reorientation of industry to fulfill defense orders, the production of agricultural machinery and the size of its supplies to the country significantly decreased). There were about 33.2 thousand tractors and 13.1 thousand combines in 1940 in the Rostov region, Krasnodar and Ordzhonikidze (now Stavropol) territories. On average, one Southern Russian collective farm accounted for about 6 tractors and more than 2 combines in 1940, while the average for the Russian Soviet Federative Socialist Republic was up to 1.7 tractors and less than one combine. Thus, even in the late 1930s, the Southern Russian regions were among the most mechanized in the Russian Soviet Federative Socialist Republic (the RSFSR).

Table 1. The placement of tractors in the districts and regions of the North Caucasus Region and their significance "in translation to arable significance" (on August 1, 1927).

\begin{tabular}{|c|c|c|c|}
\hline $\begin{array}{c}\text { Districts And } \\
\text { Regions }\end{array}$ & $\begin{array}{c}\text { The Planted Area } \\
\text { (In Acres) }\end{array}$ & $\begin{array}{c}\text { The Number Of } \\
\text { Tractors }\end{array}$ & $\begin{array}{c}\text { Value } \\
\text { (In \%) }\end{array}$ \\
\hline Donetsk & 449391 & 262 & 11.6 \\
\hline Shakhtinsky & 531254 & 216 & 8.1 \\
\hline Salsky & 617510 & 275 & 8.9 \\
\hline Taganrog & 284486 & 197 & 13.8 \\
\hline Don & 1035000 & 553 & 10.7 \\
\hline Stavropol & 1119240 & 441 & 7.8 \\
\hline Kuban & 1517128 & 791 & 10.4 \\
\hline Chernomorsky & 85737 & 44 & 10.2 \\
\hline Maikop & 193970 & 178 & 18.3 \\
\hline Armavir & 960321 & 784 & 16.2 \\
\hline Tersky & 839221 & 516 & 12.3 \\
\hline Adygea region. & 97753 & 52 & 10.6 \\
\hline Kabardino-Balkaria & 121240 & 170 & 28 \\
\hline North Ossetia & 90012 & - & - \\
\hline Ingushetia & 47125 & - & - \\
\hline Sunzhensky & 40103 & 286 & 18.9 \\
\hline Karachay- & 27282 & - & - \\
\hline Cherkessia & 96817 & - & - \\
\hline Chechen & & & \\
\hline
\end{tabular}

During the 1930s in addition to quantitative changesthe USSR tractor fleet also underwent positive qualitative changes, which led to increasing in the number and specific weight of tracked tractors. From 1927 to 1928 1,1 thousand wheeled tractors and 157 tracked tractors were manufactured at the Soviet factories, from 1928 to $1929-3,1$ thousand and 231, respectively, in 1932 - 48,4 thousand and 488 (Liashenko, P. I. the History of the national economy of the USSR, v. III, p. 334). In June 1933, the Chelyabinsk Tractor Plant (ChTP), which produced heavy-duty ligroin tractors ChTP ("Stalinits"), entered service. Andin the late 1930s. the Stalingrad (STP) and Kharkov (KhTP) tractor plants were opened to the production of medium-power heavy-duty tractors. Therefore, if in 1933 tracked tractors made up $2.9 \%$ of the USSR tractor fleet, then in 1937 - already 30.5 
$\%$, in 1938-65.5\%. The production of a large number of tracked tractors, more powerful, economical and productive than wheeled ones, significantly increased labor productivity in the agricultural sector and enhanced the effect of mechanization. Tracked tractors, unlike wheeled tractors, could work on swampy and heavily moistened soils, not to mention their power and productivity [15]. For example, the Chelyabinsk Tractor Plant surpassed in the wheeled tractor production the Stalingrad (STP) and Kharkov (KhTP) tractor plantstwice in power, three times in performance. The efficiency coefficient of medium power for tracked tractors ofthe Stalingrad (STP) and Kharkov (KhTP) tractor plantswas 20-25\% higher than for wheeled tractors of the same brands.

It should be emphasizedthat the Soviet designers tried to develop and introduce into production fundamentally innovative types of tractors. In the 1920s experiments on electric plowing were conducted in the USSR, and initially electric plowing was tested. In this case electric winches were installed on both sides of the field area, which moved the plow through the field with the help of a cable (winding it). Since the beginning of the 1930s tests of electric tractors began, which were more maneuverable in comparison with the winches. In this case electric transmission lines were arranged in the fields every kilometer, to which an electric tractor was connected via a mobile substation using a cable. Thanks to this, the tractor could move independently on the field. With increased activity, such tests continued in the second half of the decade under review, as at that time the financial and material resources of the Soviet state significantly increased, because the organizational and economic state of the collective farm system strengthened too, and the situation in the village significantly improved compared to the hardships and hardships of the "great turning point".

We should add that work on the introduction of electrical equipment into agricultural production was also carried out in other directions. In particular, in individual model farms of the Soviet Union (as a rule, in state farms), electric milking and electric threshing were already used in the early 1930s. But the proliferation of such valuable experience to other farms did not have to dream for obvious reasons, among which the first place was out of a low level of Soviet industry development, which was unable to provide livestock milking machines, the organizational-economic weakness of many of farms and the vast majority of collective farms, etc.

At the same time, tests of gas-generating tractors were launched in the USSR. Gas engine did not work on liquid fuel (gasoline, diesel), and in solids: wood, peat, straw briquettes, reeds, coal, etc. The develop-ment and testing of domestic gas engines was carried out in the first half of the 1930s; at the same time USSR bought them-tailors samples of such engines from foreign countries. By the end of the 1930s, measures for the development and introduction of gas-generating equipment into production - not only tractors, but also motor vehicles-were intensified. This was facilitated by the decision of the USSR government on the production and introduction of gas-generating tractors and automobiles, having been adopted in February 1938. In addition, at the XVIII Congress of the All-Union Communist Party that held in March 1939, where it was stated that in order to save fuel, all the machines used in logging, as well as a significant part of the agricultural tractor fleet and the automobile fleet, should be converted to gas generators.

Indeed, gas generators made it possible to achieve serious savings in liquid fuel: it was an extremely important task in the late 1930s, because at that time the Soviet Union was facing an imminent war and the army needed oil products in the largest possible volumes. If an ordinary Kharkov (KhTP) tractor plants consumed $20 \mathrm{~kg}$ of kerosene per 1 ha, then a gas-generating tractor of the same plant (KhTP-T-2G) needed $65 \mathrm{~kg}$ of wood chocks to process the same area, and a gas-generating tractor of the Chelyabinsk Tractor Plant (ChPZ-SG65) only 50-55 kg of chocks. At the same time both conventional and gas- 
powered tractors were almost equal in terms of production capabilities and parameters; the latter were only slightly inferior to the former.

On the basis of the taken decisions in the period from October 1 to November 15, 1938 in one of the suburban farms near Kharkov and in the second teaching and experimental farm on the station- Camel (now Zernograd) in the Rostov region gas-tracked tractors from Kharkov and Chelyabinsk tractor plants were tested. Based on the results of the tests, it was concluded that it was possible to use gas-generator tractors in production, although it was noted that it was necessary to eliminate a number of technical defects and refine the gasgenerator unit in order to improve fire safety, the strength of its attachment to the tractor, etc. Moreover, the ChTP manufacturing plant had not eliminated these shortcomings by 1939 and it was necessary to deal with them already during the tractor operation. Nevertheless, gas generators went into series and began to arrive in state farms and machine-tractor stations.

In 1938the share of gas-generating ChTP in the tractor fleet of the USSR was $1.1 \%$, KhTZ-NATI-0.5\%, since their production was still experimental. Serial production of such tractors began in 1939, called "the first year of serial domestic gas generator construction" (1939 - the first year of the domestic gas generator construction // Automotive and tractor business. 1939. No. 12, p. 1). According to the plans, in 1939, 7 thousand ChTP and KhTP gas-generating tractors were to go to the collective farm fields, and both the Chelyabinsk and Kharkov plants managed to fulfill the plans for the first two quarters of this year almost completely, producing 1,488 and 1,153 tractors, respectively. At the same time work continued on improving the main components and parts of gas-generating tractors in order to increase engine power, to improve gas cleaning and cooling, etc.

In the same year, 1939, mass training of machine operators for gas-generating tractors began. In March 1939 the People's Commissar of the USSR issued an order, according to which it was necessary to train more than 3,000 tractor drivers for ChTP tractors in 1.5 months and 1,435 in 2.5 months; and 2,200 and 2,075 tractor drivers for KhTP tractors, respectively. Moreover, the order did not mention the Don, Kuban and Stavropol regions among the regions where tractor drivers were supposed to train and work. Because those regions were not particularly rich in forest, theywere considered not the most suitable for the use of gas-generating tractors. Indeed, it seemed most optimal to use gas-powered tractors in forest-rich regions and, especially, not in agriculture, but in logging, where cheap fuel was available in abundance.

Still, this does not mean that the process of introducing gas-generating tractors has not affected the South of Russia in any way. The documents and materials available to us allow us to assert that the gas-generating equipment was not planned to be sent on a large scale to the Don, Kuban and Stavropol regions. However, the local leadership showed interest in such developments, because, like the government of the USSR, they saw them as a powerful means of saving oil products and believed that in the South of Russia there were still opportunities to provide the same gas generators with solid fuel. Based on such considerations, the Rostov Regional Executive Committee in June 1939 adopted a resolution that provided for testing local coal as fuel for gas generators. At the beginning of 1940 the leaders of the Kuban automobile and tractor enterprises concerned about the acute shortage of liquid fuel (sent primarily to the army), seriously argued that the region had all the opportunities to transfer $60-70 \%$ of the equipment fleet to gas generators. Thus, the authorities in the south of Russia were looking for opportunities to create conditions for the widespread use of gas-generating equipment. 


\section{Discussion}

The testing of electric and gas-generating tractors and their use in agriculture clearly demonstrated the advantages of this innovative technology. According to the testers, the electric tractor plowed deeper than conventional tractors, which allowed to increase the yield by $17 \%$; a considerable (more than 10 rubles per 1 ha) fuel and lubricants savings were added to it, which were required by $70 \%$ less than for tractors with an internal combustion engine. Tractor drivers were delighted with the comfortable working conditions on the electric tractor, claiming that in terms of hygienic conditions, working on them "cannot be compared to working on thermal tractors" (Sergey Suvorov. Experience of economic electric plowing in the Engel MTS // Mechanization and electrification of socialist agriculture. 1938. No. 8-9. p. 61; Nikolay Sazonov. Electricity in the service of the Socialist Rural Economy // Mechanization and electrification of socialist agriculture. 1940. No. 3. S. 41). It is no coincidence that today we are talking about the electric transformation of diesel agricultural tractors [16]. There were also advantages of electric winches: there was no need to waste fuel, the soilwas not damaged during plowing and so on [17].

However, the advantages of electrical engineering paled before its disadvantages. Electric plowing with winches was fraught with certain dangers for the lives of workers and required higher cost of cables (which also failed after a while as a result of periodic twisting, which happened with each turn of the electric plow in the field). Electric tractors were also difficult to maintain, and working on them was also associated with a certain risk to life. The most important thing was that both electric winches and electric tractors needed (and were limited) power lines, which in the period under review were not so often found in the fields of state farms and collective farms. Therefore, throughout the 1930s electric plowing remained no more than an experience (Pavel Listov, Viktor Stetsenko. Test of electric tractors / / Mechanization and electrification of socialist agriculture. 1939. No. 7. P. $24-25)$.

It seemed that, unlike electric tractors, gas generators have much more advantages and a great future. But they also showed a lot of weaknesses. In agricultural production gasgenerating tractors were often used unsatisfactorily: according to the People's Commissariat of Agriculture of the USSR by April 1940, the cost of such tractors in some MTS (Machine and tractor station) reached $50-60 \%$ of the working time. Most often it happened due to a shortage or poor training of personnel, technical defects and difficulties in operation.

Special consideration should be given to fuel for gas-generating equipment, which (along with the corresponding installation for its combustion) turned this equipment into a serious competitor for mechanisms with an internal combustion engine. I must say that, judging by the content of documents and publications in periodicals, fuel was one of the biggest problems in the operation of gas-generating tractors and cars. Often the wood for gas-generator engines was of extremely poor quality, and its burning in the gas generator led to clogging of it and the termination of its operation. Moreover, it often happened because few of the workers of the Soviet machine-tractor stations knew what kind of fuel was required for certain gas-generator tractors. And there were a lot of nuances there. The best fuel was considered to be solid wood (oak, maple, elm, birch), which gave the most durable charcoal and a relatively small amount of fines and dust when gasified. Soft deciduous and coniferous wood was worse, as it led to generator contamination. The size of the wood chocks was very important. For CHTS-SG-65 chocks with a length of 4-8 cm, a width and a height of 5 by $5 \mathrm{~cm}$ were required; for KHTP-T-2G with a length of up to $6 \mathrm{~cm}$, a width and a height of also 5 by $5 \mathrm{~cm}$. The absence of sawdust, dirt, and wood chips was required and the moisture content of the wood should not exceed $20 \%$ (special dryers carbonization were used to control the moisture content of the fuel). It was even more difficult to deal with peat, because there were many varieties that differed in ash content, 
humidity, etc. In addition, gas-generating tractors were sufficiently fire-prone: it is no accident that in the memo to tractor drivers who worked on such machines, several items were specifically dedicated to fire safety. All it significantly hindered their operation and competitiveness in comparison with liquid fuel tractors.

\section{Conclusions}

So, in the 1930s, work on the creation, testing and introduction into production of such innovative means of agricultural mechanization as electric and gas-generating tractors was carried out very actively. During the tests and operation electric and, especially, gasgenerating tractors demonstrated a number of their undoubted advantages over equipment with an internal combustion engine. However, they had more disadvantages, which did not allow them to gain a leading position in the agricultural sector. A new impulse to the development of gas-generating facilities was given by the Great Patriotic war, as it was admitted that "the introduction of gas tractors in agricultural production is essential in order to reduce the consumption of liquid fuels" (Maxim Weiner. Maximally reduce the consumption of liquid fuel / / Socio-economic agriculture. 1941. No. 7-8. p. 28), which was known as the "blood" of a modern "engine war". But in the post-war period the production and the usage of gas-generating tractors gradually came to naught, mainly due to operational difficulties. Wheeled and tracked electric tractors of improved designs were also tested after the war (in particular, in the fields of the Zelenchuk and Kursk districts of Stavropol) (New developments in the field of agricultural production (Facts and figures). Stavropol, 1951. p. 4; Vladimir Elistratov. Stavropol Territory during the post-war five years. Stavropol, 1952. p. 24), but they never went into production.

\section{References}

1. Chi Zhang, Noboru Noguchi, Computers and Electronics in Agriculture 142, 79 - 90 (2017), doi.org/10.1016/j.compag.2017.08.017

2. Wan-Soo Kim, Yong-Joo Kim, Yeon-Soo Kim, Soil and Tillage Research 207 (2021) doi.org/10.1016/j.still.2020.104851

3. D. Lovarelli, J. Bacenetti, Biosystems Engineering 186, $204-213$ (2019) doi.org/10.1016/j.biosystemseng.2019.07.011

4. J.M. Rudolphi, Sh. Campo, D.S. Rohlman, Journal of Adolescent Health 62, $605-611$ (2018) doi.org/10.1016/j.jadohealth.2017.11.300

5. S. Karthikeyan, M. Periyasamy, M. Yuvaraj, Materials Today: Proceedings 33, 34383442 (2020) doi.org/10.1016/j.matpr.2020.04.908

6. Ł. Rymaniak, P. Lijewski, A. Jagielski, Computers and Electronics in Agriculture 173 (2020) doi.org/10.1016/j.compag.2020.105405

7. J. Bacenetti, D. Lovarelli, D. Pessina, Biosystems Engineering 171, 30 - 40 (2018) doi.org/10.1016/j.biosystemseng.2018.04.014

8. G. Molari, M. Mattetti, S. Fiorati, Biosystems Engineering 187, 160 - 170 (2019) doi.org/10.1016/j.biosystemseng.2019.09.001

9. M. Cutini, M. Brambilla, C. Bisaglia, Biosystems Engineering 185, 35 - 44 (2019) doi.org/10.1016/j.biosystemseng.2019.02.015

10. Shuo Chen, Xiaohuan Lan, Journal of Development Economics 147 (2020) doi.org/10.1016/j.jdeveco.2020.102536 
11. Khoshnam Shojaei, European Journal of Control 59, 82 - 98 (2021) doi.org/10.1016/j.ejcon.2021.02.005

12. S.M. Shafaei, M. Loghavi, S. Kamgar, Measurement 165 (2020) doi.org/10.1016/j.measurement.2020.108134

13. Huisong Gao, Jinlin Xue, Sustainable Energy Technologies and Assessments 39, (2020) doi.org/10.1016/j.seta.2020.100697

14. N. Regazzi, M. Maraldi, G. Molari, Biosystems Engineering 186, 214 - 227 (2019) doi.org/10.1016/j.biosystemseng.2019.07.006

15. S. Brain, Song of the forest: Russian forestry and Stalinist environmentalism, 1905 1953 (University of Pittsburgh press, Pittsburgh, 2011)

16. Huisong Gao, Jinlin Xue, Sustainable Energy Technologies and Assessments 39 (2020) doi.org/10.1016/j.seta.2020.100697

17. Xueyuan Liu, Jinqu Liu, Chao He, Biosystems Engineering 198, 280 - 290 (2020) doi.org/10.1016/j.biosystemseng.2020.08.018 